\title{
PENGGUNAAN METODE MIND MAPPING UNTUK MENINGKATKAN HASIL BELAJAR PESERTA DIDIK PADA MATA PELAJARAN EKONOMI KELAS XII MIPA 1 SMA NEGERI 2 PEKANBARU \\ (Use Of Mind Mapping Method To Improve Students Learning Outcomes In Economic Learning Class XII MIPA 1 SMA Negeri 2 Pekanbaru)
}

Angreta

Email : angretajohn@gmail.com

*) Guru SMA Negeri 2 Pekanbaru

\begin{abstract}
This study aims to determine the increase of students learning outcomes through learning activities using Mind Mapping method in class XII MIPA 1 SMA Negeri 2 Pekanbaru. This research was conducted in July to September 2019. The subject was students of class XII MIPA 1 of SMA Negeri 2 Pekanbaru, totaling 36 students consist of 17 men and 19 women. This type of research is classroom action research. This research was conducted in two cycles for six meetings. Each meeting using the Mind Mapping method with consists of identifying the topic, planning the tasks to be studied, carrying out investigations, preparing final reports, presenting final reports, conclusions and evaluations. The research found that the usage of mind mapping method can improve the learning outcomes of class XII MIPA 1 SMA Negeri 2 Pekanbaru. The increasing was seen in the results of the first cycle with an average value of 84.13 and 92.66 in the second cycle. The percentage of students who pass the passing grade increase from $77.77 \%$ to $100 \%$. Classroom action research with optimal usage of mind mapping method can improve learning outcomes in economic subject.
\end{abstract}

Keywords: Learning Outcomes, Economics, Mind Mapping

\section{PENDAHULUAN}

Slameto (2015) mengungkapkan guru berperan dalam mengelola seluruh pembelajaran dengan menciptakan kondisi belajar sedemikian rupa, sehingga setiap peserta didik dapat belajar secara efektif dan efesien dengan hasil belajar yang baik. Berdasarkan hasil observasi yang dilakukan terdapat beberapa masalah yang ditemukan di kelas XII MIPA 1 SMA Negeri 2 Pekanbaru. Masalah tersebut yaitu kurangnya motivasi peserta didik dalam belajar Ekonomi. Peserta didik kurang kreatif dalam mencari sumber belajar lain. Peserta didik cenderung lebih tergantung dari catatan yang diberikan guru, dalam pembelajaran guru masih banyak menggunakan metode ceramah dan pembelajaran berpusat pada guru.

Teknik mencatat kreatif dapat menghasilkan pengetahuan dari diri sendiri membuat peserta didik menjadi mandiri, kreatif. Mencatat dengan kreatif bisa membuat peserta didik mengingat materi itu dengan mudah. Mind Mapping atau peta pikiran adalah metode mempelajari konsep yang ditemukan oleh Tony Buzan. Metode pembelajaran Mind Mapping adalah metode pembelajaran yang dirancang untuk mengembangkan pengetahuan siswa dengan kegiatan kreatif menyusun ideide pokok dari sebuah konsep menjadi sebuah peta pikiran yang mudah dipahami oleh siswa (Darusman, 2014).

Berdasarkan uraian tersebut, maka peneliti melaksanakan penelitian dengan judul "Penggunaan Metode Mind Mapping Untuk Meningkatkan Hasil Belajar Peserta Didik Pada Mata Pelajaran Ekonomi di Kelas XII MIPA 1 SMA Negeri 2 Pekanbaru". 
Metode Mind Mapping

Menurut Buzan (2006) Mind Mapping adalah cara mencatat yang kreatif, efektif, dan secara harfiah akan "memetakan" pikiran-pikiran kita.

Swadarma (2013) menjelaskan beberapa keunggulan lain dari model pembelajaran mind mapping, yaitu sebagai berikut: (a). Meningkatkan kinerja manajemen pengetahuan; (b) Memaksimalkan sistem kerja otak; (c) Saling berhubungan satu sama lain sehingga makin banyak ide dan informasi yang dapat dijelaskan; (d) Memacu kreatifitas, sederhana, dan mudah dikerjakan; (e) Sewaktu-waktu dapat me-recall data yang ada dengan mudah. Pembuatan Mind Mapping lebih mudah mengemukakan pendapat secara bebas, pembagian materi dapat lebih fokus pada inti materi dan sangat memungkinkan menambahkan informasi baru. Materi lebih mudah diingat dan padat karena Mind Mapping dibuat dalam satu lembar kertas. Penambahan warna, simbol dan garis melengkung membuat otak lebih responsif dalam memasukkan dan mengambil kembali informasi.

\section{Hasil Belajar}

Menurut Djamarah \& Zain (2013) hasil belajar adalah penilaian pendidik tentang kemajuan peserta didik dalam segala hal yang dipelajari di sekolah menyangkut pengetahuan atau kecakapan/keterampilan yang dinyatakan sesudah hasil penilaian.

Kegiatan belajar dapat dikatakan berhasil bila dapat mencapai hasil yang optimal. Winkel (2005) mengemukakan hasil belajar merupakan suatu bukti keberhasilan usaha yang dicapai seseorang setelah memperoleh pengalaman belajar atau mempelajari sesuatu.

\section{Pembelajaran Ekonomi}

Menurut Paul A. Samuelson dalam Sukwiaty (2007) mengemukakan bahwa ilmu ekonomi sebagai suatu study tentang perilaku orang dan masyarakat dalam memilih cara menggunakan sumber daya yang langka dan memiliki beberapa alternatif penggunaan, dalam rangka memproduksi berbagai komoditas dan penyalurannya, baik saat ini maupun di masa depan kepada berbagai individu dan kelompok dalam suatu masyarakat.

\section{METODOLOGI PENELITIAN}

Penelitian ini menggunakan rancangan penelitian tindakan kelas (classroom action research).

Subjek penelitian yaitu metode pembelajaran mind mapping, dan objek penelitian difokuskan pada kelas XII MIPA 1 SMA Negeri 2 Pekanbaru, berjumlah 36 orang yang terdiri dari 17 orang laki-laki dan 19 orang perempuan. Penelitian tindakan kelas dilaksanakan ini terdiri dari dua siklus dimana pada setiap siklusnya terdiri dari tiga kali pertemuan dan pada tiap siklusnya meliputi empat tahap yaitu perencanaan, pelaksanaan, observasi, dan refleksi. Berbagai tahap dan kegiatan pada siklus kedua pada dasarnya sama dengan siklus pertama, hanya saja tindakan yang dilakukan berbeda. Tindakan pada siklus kedua ini berdasarkan hasil refleksi pelaksanaan siklus pertama.

\section{HASIL PENELITIAN}

Siklus I

Hasil belajar yang diperoleh peserta didik pada siklus I yang didapatkan adalah sebagai berikut:

Tabel 4.1 Hasil Belajar Siklus 1

\begin{tabular}{|l|l|c|}
\hline No & \multicolumn{1}{|c|}{ Hasil Belajar } & Pencapaian \\
\hline 1. & Nilai Terendah & 80 \\
\hline 2. & Nilai Tertinggi & 100 \\
\hline 3. & Nilai Rata-Rata & 84,14 \\
\hline 4. & Jumlah Nilai $\geq 82$ & 28 \\
\hline 5. & Jumlah Siswa & 36 \\
\hline 6. & $\begin{array}{l}\text { Persentase Nilai } \geq \\
82\end{array}$ & $77,77 \%$ \\
\hline
\end{tabular}

Hasil belajar pada siklus I menunjukkan bahwa jumlah peserta didik yang 
mempunyai nilai di atas 82 sebesar $77,77 \%$ berdasarkan hasil belajar dan refleksi terhadap siklus I maka dilaksanakan siklus II

Siklus II

Pembelajaran dengan metode mind mapping yang dilakukan pada siklus II, tindakan perbaikan yang dilakukan peneliti adalah selalu menggali pemahaman peserta didik mengenai materi pada setiap pertemuan, dan selalu memberikan bimbingan dan arahan pada peserta didik sehingga lebih aktif dalam menjawab pertanyaan, memberikan argumenatsi, saling membantu, saling mendukung, mengerjakan tugas serta tanggung jawab individu dan dalam mempresentasekan hasil diskusi, sehingga dengan mudah menarik suatu kesimpulan tentang materi yang sedang berlangsung dalam proses pembelajaran.

Tes hasil belajar peserta didik yang dilakukan akhir siklus II, diperoleh data sebagai berikut:

Tabel 4.2. Hasil Belajar Siklus II

\begin{tabular}{|c|l|c|}
\hline No & \multicolumn{1}{|c|}{ Hasil Belajar } & Pencapaian \\
\hline 1 & Nilai Terendah & 85 \\
\hline 2 & Nilai Tertinggi & 100 \\
\hline 3 & Nilai Rata-rata & 92,66 \\
\hline 4 & Nilai Siswa $\geq 82$ & 36 orang \\
\hline 5 & Jumlah Siswa & 36 orang \\
\hline 6 & $\begin{array}{l}\text { Persentase Nilai } \geq \\
82\end{array}$ & $100 \%$ \\
\hline
\end{tabular}

Berdasarkan hasil belajar siklus II, menunjukkan bahwa yang memperoleh nilai diatas 82 sudah lebih dari $80 \%$. Maka dapat disimpulkan bahwa pembelajaran ekonomi menggunakan metode mind mapping pada penelitian ini sudah cukup sampai pada siklus II.

\section{PEMBAHASAN}

Aktivitas peserta didik dalam pembelajaran meningkat, sehingga hasil belajar peserta didik dari siklus I ke siklus II terus meningkat dengan signifikan dari rata-rata 84,14 menjadi 92,66. Supadmi (2017) mengemukakan peningkatan aktivitas belajar siswa tentu sangat berpengaruh terhadap peningkatan hasil belajar yang dicapai oleh siswa setelah diterapkannya metode pembelajaran Mind Mapping.

Berdasarkan hasil belajar yang dicapai pada siklus I dan siklus II, peningkatan persentase hasil belajar peserta didik dengan metode mind mapping pada siklus I dari $77,77 \%$ (28 orang dari 36 orang) berada pada kategori kurang menjadi 100\% (36 orang dari 36 orang). Menunjukkan adanya perbaikan siklus I yang dilakukan pada siklus II.

Pencapaian hasil belajar peserta didik sudah sesuai dengan yang diharapkan tidak lepas dari peran pengawasan peneliti dalam proses pembelajaran. Pada siklus II terjadi perubahan-perubahan yang baik, hasil belajar peserta didik menjadi optimal, semangat belajar peserta didik meningkat, peserta didik aktif dalam proses pembelajaran, dan suasana pembelajaran menjadi lebih kondusif.

\section{KESIMPULAN}

Berdasarkan hasil penelitian dan pembahasan maka dapat disimpulkan sebagai berikut:

1. Penggunaan metode mind mapping dapat meningkatan aktivitas, kreatifitas peserta didik dan hasil belajar ekonomi kelas XII MIPA 1 SMA Negeri 2 Pekanbaru tahun pelajaran 2019-2020.

2. Nilai rata-rata peserta didik untuk pembelajaran ekonomi di kelas XII MIPA 1 meningkat dari rata-rata 84,14 pada siklus I menjadi 92,66 pada siklus II.

3. Hasil belajar peserta didik meningkat, persentase nilai $\geq 82$ yaitu 28 orang pada siklus I menjadi 36 orang pada siklus II. 


\section{REFERENSI}

Buzan, T. 2006. Mind Map untuk Meningkatkan Kreativitas. Jakarta: PT. Gramedia Pustaka Utama.

Darusman, R. 2014. Penerapan Metode Mind Mapping (Peta Pikiran) untuk Meningkatkan Kemampuan Berpikir Kreatif Matematik Siswa SMP. Infinity Jurnal Ilmiah. 3(2). Hlm. 16473

Djamarah, S, B, \& Zain, A. 2013. Strategi Belajar Mengajar. Jakarta: Rineka Cipta.

Slameto. 2015. Belajar dan FaktorFaktor yang Mempengaruhinya. Jakarta: Rineka Cipta.

Sukwiaty, dkk. 2007. Ekonomi 2 SMA/MA Kelas XI. Jakarta: Yudistira.

Supadmi, N. L, dkk. 2017. Penerapan Metode Mind Mapping untuk Meningkatkan Aktivitas dan Hasil Belajar Kimia Siswa Kelas X MIA. Jurnal Pendidikan Kimia Indonesia. 1(2). Hlm.48-52.

Swadarma, D. 2013. Penerapan Mind Mapping dalam Kurikulum Pembelajaran. Jakarta: PT Elex Media Komputindo

Winkel,W.S. 2005. Psikologi Pendidikan Evaluasi Belajar. Jakarta: Gramedia. 